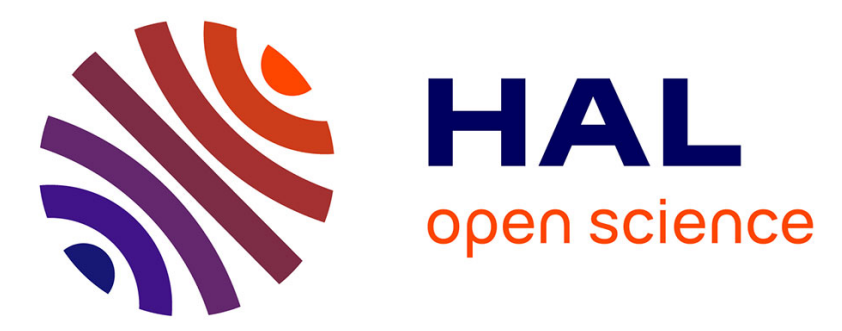

\title{
New Mn-TiO2 aerogel catalysts for the low-temperature selective catalytic reduction of $\mathrm{NOx}$
}

Jihene Arfaoui, Abdelhamid Ghorbel, Carolina Petitto, Gerard Delahay

\section{To cite this version:}

Jihene Arfaoui, Abdelhamid Ghorbel, Carolina Petitto, Gerard Delahay. New Mn-TiO2 aerogel catalysts for the low-temperature selective catalytic reduction of NOx. Journal of Sol-Gel Science and Technology, 2021, 97, pp.302-310. 10.1007/s10971-020-05451-4 . hal-03133561

\section{HAL Id: hal-03133561 \\ https://hal.science/hal-03133561}

Submitted on 6 Feb 2021

HAL is a multi-disciplinary open access archive for the deposit and dissemination of scientific research documents, whether they are published or not. The documents may come from teaching and research institutions in France or abroad, or from public or private research centers.
L'archive ouverte pluridisciplinaire HAL, est destinée au dépôt et à la diffusion de documents scientifiques de niveau recherche, publiés ou non, émanant des établissements d'enseignement et de recherche français ou étrangers, des laboratoires publics ou privés. 


\title{
New $\mathrm{Mn}-\mathrm{TiO}_{2}$ aerogel catalysts for the low-temperature selective catalytic reduction of NOx
}

\author{
Jihene Arfaoui ${ }^{* a}$, Abdelhamid Ghorbel ${ }^{\mathrm{a}}$, Carolina Petitto $^{\mathrm{b}}$, Gerard Delahay ${ }^{\mathrm{b}}$ \\ anniversité Tunis El Manar, Laboratoire de Chimie des Matériaux et Catalyse, Département de Chimie, Faculté \\ des Sciences de Tunis, Campus Universitaire Farhat Hached d'El Manar, 2092, Tunis, Tunisia. \\ bICGM, University of Montpellier, ENSCM (MACS), CNRS, Montpellier, France \\ * Corresponding author: E-mail address: jihene.arfaoui@ fst.utm.tn; jihenar@yahoo.fr \\ Tel: +216 23020273, Fax: +21671875008
}

\begin{abstract}
A new series of Mn-based catalysts $\left(\mathrm{Mn}-\mathrm{TiO}_{2}, \mathrm{Ce}-\mathrm{Mn}-\mathrm{TiO}_{2}, \mathrm{Mn}-\mathrm{TiO}_{2}-\mathrm{SO}_{4}{ }^{2-}\right.$ and $\left.\mathrm{Ce}-\mathrm{Mn}-\mathrm{TiO}_{2}-\mathrm{SO}_{4}{ }^{2-}\right)$ were successfully elaborated using the sol gel method associated to supercritical drying approach for the low temperature NO-SCR by $\mathrm{NH}_{3}$. The physicochemical properties of aerogel powders were examined by XRD, $\mathrm{N}_{2}-$ Physisorption at $77 \mathrm{~K}, \mathrm{NH}_{3}-\mathrm{TPD}, \mathrm{H}_{2}$-TPR, and DRUV-Vis spectroscopy. It was shown that all the catalysts develop essentially the diffraction peaks of $\mathrm{TiO}_{2}$ anatase phase and are characterized by a nanometer size (ranging between $\sim 5$ and $9 \mathrm{~nm})$, developed mesoporous texture, high surface area $\left(\mathrm{S}_{\mathrm{BET}}>104 \mathrm{~m}^{2} / \mathrm{g}\right)$ and large porosity $\left(\mathrm{V}_{\mathrm{PT}}>0.24 \mathrm{~cm}^{3} / \mathrm{g}\right)$. The incorporation of $\mathrm{Ce}$ and $/ \mathrm{or} \mathrm{SO}_{4}{ }^{2-}$ influences differently the structural, textural, acidic and redox properties of Mn derived sol gel catalysts and consequently affects their SCR activity. High NO conversions $(>75 \%)$ into essentially $\mathrm{N}_{2} \mathrm{O}$ are obtained at low temperatures $\left(150-270{ }^{\circ} \mathrm{C}\right.$ ) over $\mathrm{Mn}^{-\mathrm{TiO}_{2}}$ and $\mathrm{Ce}-\mathrm{Mn}-\mathrm{TiO}_{2}$ aerogel systems. The addition of sulfate modifies the nature of Mn species and noticeably reduces the low temperature reactivity of catalysts $\left(\mathrm{T}<300{ }^{\circ} \mathrm{C}\right)$. However, it induces, thanks to the contribution of many strong acid sites, a substantial increase of the $\mathrm{NO}$ conversion into $\mathrm{N}_{2}$ at higher temperatures $\left(\mathrm{T}>300^{\circ} \mathrm{C}\right)$ leading to highly active and $\mathrm{N}_{2}$-selective $\mathrm{Mn}-\mathrm{TiO}_{2}-\mathrm{SO}_{4}{ }^{2-}$ and Ce-Mn- $\mathrm{TiO}_{2}-\mathrm{SO}_{4}{ }^{2-}$ sulfated catalysts. Above $90 \% \mathrm{NO}$ conversion into $\mathrm{N}_{2}(100 \%)$ was reached, in the NO-SCR by $\mathrm{NH}_{3}$, over the new Ce-Mn- $\mathrm{TiO}_{2}-\mathrm{SO}_{4}{ }^{2-}$ aerogel catalyst, in the 450$500{ }^{\circ} \mathrm{C}$ temperature range.
\end{abstract}

Key words: Sol Gel method, Aerogel, $\mathrm{Mn}-\mathrm{TiO}_{2}$, Cerium, Sulfate, Low temperature NO-SCR by $\mathrm{NH}_{3}$

\section{Introduction}

"Aerogels" are an exceptional class of mesoporous/macroporous materials derived from organic, inorganic or hybrid molecular precursors and usually prepared via the sol-gel method associated to an appropriate drying process, mainly supercritical one, which preserve both the three-dimensional arrangement and highly 
porous texture of solids. The unique and exclusive properties of these materials such as low density (0.003-0.5 g $\left.\mathrm{cm}^{-3}\right)$, considerably high surface area $\left(500-1200 \mathrm{~m}^{2} / \mathrm{g}\right)$, large porosity $(80 \%-99.8 \%)$ and adjustable surface chemistry with the ability to be processed into a variety of morphologies and sizes [1] made them suitable for various applications extending from thermal and acoustic insulation to biomedical and pharmaceutical applications [2]. In recent years, major interest has been devoted to aerogels as heterogeneous catalysts, photocatalysts or catalyst supports for air and water cleaning reactions such as: VOCs oxidation, Methane reforming, Preferential oxidation of CO, Fenton and Fenton-like processes, Ozonation and deNOx applications (NO-SCR) [2].

Selective catalytic reduction of $\mathrm{NO}$ by $\mathrm{NH}_{3}$ (NO-SCR) is until now considered the most efficient and economic technology for controlling NOx emissions from stationary sources and diesel vehicles [3]. The commercially used catalysts are principally $\mathrm{WO}_{3}$ or $\mathrm{MoO}_{3}$ doped $\mathrm{V}_{2} \mathrm{O}_{5} / \mathrm{TiO}_{2}$ [4] which exhibit excellent SCR performances between 300 and $400{ }^{\circ} \mathrm{C}$ but it has several drawbacks such as: narrow reaction temperature range, production of $\mathrm{N}_{2} \mathrm{O}$ at high temperature, volatility and toxicity of vanadium [5-6]. Hence, there has been a lot of interest to develop environmentally friendly and highly active free vanadium catalysts for the low-temperature SCR process $\left(<200^{\circ} \mathrm{C}\right)$.

A variety of supported transition metal oxides (e.g., $\mathrm{V}_{2} \mathrm{O}_{5}, \mathrm{NiO}, \mathrm{Co}_{3} \mathrm{O}_{4}, \mathrm{Fe}_{3} \mathrm{O}_{4}, \mathrm{MnO}_{2}$, etc.) and transition metals (e.g., Co, V, Cu, Fe, Mn, etc.), have been developed for the NO-SCR process [7,8]. Particularly, manganesecontaining catalysts [8,9], such as: $\mathrm{MnO}_{\mathrm{x}} / \mathrm{TiO}_{2}$ [10], $\mathrm{MnO}_{\mathrm{x}} / \mathrm{CeO}_{2}$ [11], $\mathrm{MnO}_{\mathrm{x}} / \mathrm{Al}_{2} \mathrm{O}_{3}$ [12], $\mathrm{MnO}_{\mathrm{x}} /$ zeolite $[13,14]$ and $\mathrm{MnO}_{\mathrm{x}}$ /active carbon [15], has attracted much attention due to the excellent redox ability of Mn [8]. Peña et al. [16] showed that among various transition metal oxides supported on $\mathrm{TiO}_{2}$, manganese based catalyst is the best candidate for the low-temperature SCR reaction and the activity decreases following this order: $\mathrm{Mn}>\mathrm{Cu} \geq \mathrm{Cr}>>$ $\mathrm{Co}>\mathrm{Fe}>>\mathrm{V}>>$ Ni. Nevertheless, Smirniotis et al. [17] examined the effect of support $\left(\mathrm{TiO}_{2}, \mathrm{SiO}_{2}\right.$ and $\left.\gamma-\mathrm{Al}_{2} \mathrm{O}_{3}\right)$ on the NO-SCR activity of various metal oxides (MnOx, VOx, $\mathrm{NiOx}, \mathrm{CuOx}$ and $\mathrm{CrOx}$ ) and demonstrated that $\mathrm{MnOx} / \mathrm{TiO}_{2}$ system exhibits the best catalytic performance.

Recently, much attention was devoted to $\mathrm{Mn}-\mathrm{Ce} / \mathrm{TiO}_{2} \mathrm{SCR}$ catalysts due to their nontoxicity and exceptional low-temperature activity. These systems showed extraordinary SCR-activity between 100 and $200{ }^{\circ} \mathrm{C}$ [18-22] because manganese oxides ( $\mathrm{MnOx})$ have many types of oxidative states and possesses several kinds of active oxygen which is necessary to complete the SCR reaction cycle [23]. Meanwhile, ceria $\left(\mathrm{CeO}_{2}\right)$ has been proved as promoter on the SCR catalysts due to its unique oxygen storage capacity (OSC) and redox properties: this element can store and release oxygen via the redox shift between $\mathrm{Ce}^{4+}$ and $\mathrm{Ce}^{3+}$ under the oxidizing and reducing conditions, respectively [24,25]. It has been verified that the SCR activity of Mn species is strongly 
influenced by the Mn oxidation state, crystallinity, specific surface area and morphology of catalyst [26] which are strongly affected by the preparation method. Kaptejin et al. [27] reported that the SCR activity of Mn species decreases in this order $\mathrm{MnO}_{2}>\mathrm{Mn}_{5} \mathrm{O}_{8}>\mathrm{Mn}_{2} \mathrm{O}_{3}>\mathrm{Mn}_{3} \mathrm{O}_{4}>\mathrm{MnO}$. Furthermore, Kang et al. [28] correlated the excellent activity of $\mathrm{MnOx}$ catalyst for the low temperatures selective catalytic reduction of NOx with its high surface area and amorphous framework structure.

It is recognized that the use of the sol-gel procedure combined to supercritical drying can produce a highly structured aerogel materials with superior textural properties (high specific surface area and porosity) which can provide more active sites in the catalyst surface [29]. On the other hand, in our previous works [30,31] we have demonstrated that the addition of $\mathrm{SO}_{4}{ }^{2-}$ groups to the composition of $\mathrm{V}_{2} \mathrm{O}_{5}-\mathrm{CeO}_{2}-\mathrm{TiO}_{2}$ and $\mathrm{V}_{2} \mathrm{O}_{5}-\mathrm{MoO}_{3}-\mathrm{TiO}_{2}$ aerogel catalysts enhances both the NO conversion and $\mathrm{N}_{2}$ selectivity at high temperatures. However, the NO-SCR activity of Ce-Mn- $\mathrm{TiO}_{2}-\mathrm{SO}_{4}{ }^{2-}$ aerogel system has not yet been studied. In this work, we investigate the SCR activity of a new series of unsulfated and sulfated $\mathrm{Mn}$ based aerogel catalysts $\left(\mathrm{Mn}-\mathrm{TiO} 2, \mathrm{Ce}-\mathrm{Mn}-\mathrm{TiO} 2, \mathrm{Mn}-\mathrm{TiO}_{2}-\mathrm{SO}_{4}{ }^{2-}\right.$ and Ce-Mn- $\left.\mathrm{TiO}_{2}-\mathrm{SO}_{4}{ }^{2-}\right)$, in a wide temperature range $\left(100-500{ }^{\circ} \mathrm{C}\right)$ under $\mathrm{O}_{2}$ rich conditions and at relatively high gas hourly space velocity "GHSV" (120.000 $\left.\mathrm{h}^{-1}\right)$.

\section{Experimental}

\section{1. Catalysts elaboration}

The aerogel samples $\left(\mathrm{TiO}_{2}, \mathrm{Mn}-\mathrm{TiO}_{2}, \mathrm{Ce}-\mathrm{Mn}-\mathrm{TiO}_{2}, \mathrm{Mn}-\mathrm{TiO}_{2}-\mathrm{SO}_{4}{ }^{2-}\right.$ and $\left.\mathrm{Ce}-\mathrm{Mn}^{-} \mathrm{TiO}_{2}-\mathrm{SO}_{4}{ }^{2-}\right)$ were synthesized via the one step sol-gel method using the same procedure reported in our previous works [30,31]. Cerium nitrate $\left(\mathrm{Ce}\left(\mathrm{NO}_{3}\right)_{3} \cdot 6 \mathrm{H}_{2} \mathrm{O}\right.$,Aldrich) and manganese nitrate $\left(\mathrm{Mn}\left(\mathrm{NO}_{3}\right)_{2} \cdot 6 \mathrm{H}_{2} \mathrm{O}\right.$, Aldrich) were used as Ce and Mn precursors. Theoretical loading of Mn and Ce were fixed to 8 and $10 \%$ wt., respectively. The sulfated samples were prepared according to the molar ratio $\mathrm{S} / \mathrm{Ti}=0.2$. All the aerogel samples were calcined for $3 \mathrm{~h}$ at $500{ }^{\circ} \mathrm{C}$ under $\mathrm{O}_{2}$ flow $\left(30 \mathrm{~mL} \cdot \mathrm{min}^{-1}\right)$.

\section{2. Catalysts characterization and activity test}

The textural properties of aerogel catalysts were determined by $\mathrm{N}_{2}$-adsorption-desorption analysis, which was carried out at $77 \mathrm{~K}$ on a Micromeritics ASAP 2020 apparatus. Prior to $\mathrm{N}_{2}$ adsorption, the samples were degassed at $200{ }^{\circ} \mathrm{C}$ for $6 \mathrm{~h}$ to desorb moisture adsorbed on their surfaces and inside their porous networks. The specific surface areas were calculated by the Brunauer-Emmett-Teller (BET) equation in 0.05-0.35 partial pressure range, while, the pore volumes, average pore diameters and pore size distributions were determined by BarrettJoyner-Halenda (BJH) method from the desorption branches of the isotherms. 
The catalyst structures were examined by powder X-ray diffraction on a Brüker AXS D8 diffractometer equipped with $\mathrm{CuK} \alpha$ radiation $\left(\lambda=1.5406 \AA\right.$ ) , using a scan range from $2 \theta=2$ to $80^{\circ}$ with a step size of $0.02^{\circ}$. The crystallites size (D) of titania was calculated by the Scherrer formula applied to the most intense peak of the $\mathrm{TiO}_{2}$ anatase phase $\left(2 \theta \sim 25^{\circ}\right)$ : $\mathrm{D}=0.89(\lambda / \beta \cos \theta)$ [32], where $\theta$ is the peak position, $\beta$ is the corrected peak width at half-maximum intensity (FWHM in radians) and $\lambda$ is the wavelength of XR radiation.

Diffuse Reflectances Ultraviolet visible spectroscopy (DR-UV-vis) was carried out over the aerogels powder, at room temperature, in the $200-900 \mathrm{~nm}$ range with a speed of $960 \mathrm{~nm} \mathrm{~min}{ }^{-1}$ and an aperture of $4 \mathrm{~nm}$. PerkinElmer spectrophotometer type lambda 45 equipped with an integrating sphere type RSA-PE-20 was used as apparatus.

Temperature Programmed Desorption by Ammonia ( $\left.\mathrm{NH}_{3}-\mathrm{TPD}\right)$ was performed using an AUTOCHEM 2920 (Micromeritics) equipped with a TCD detector. Prior to $\mathrm{NH}_{3}$ adsorption, the catalyst powder $(\mathrm{m}=0.05 \mathrm{~g})$ was activated under air flow $\left(30 \mathrm{~mL} \mathrm{~min}^{-1}\right)$ at $500{ }^{\circ} \mathrm{C}\left(\operatorname{ramp~} 10^{\circ} \mathrm{C} \mathrm{min}-1\right)$ for $30 \mathrm{~min}$. After cooling to $100{ }^{\circ} \mathrm{C}$, the sample was saturated with ammonia $\left(5 \mathrm{vol} \% \mathrm{NH}_{3}\right.$ in $\mathrm{He}$, flow rate $\left.=30 \mathrm{~mL} \mathrm{~min}^{-1}\right)$ for $45 \mathrm{~min}$. Then, it was flushed with $\mathrm{He}\left(30 \mathrm{~mL} \mathrm{~min}^{-1}\right)$ during $2 \mathrm{~h}$ to remove physisorbed $\mathrm{NH}_{3}$. Finally, the ammonia was desorbed in He flow (30 $\mathrm{mL} \min ^{-1}$ ) from $100{ }^{\circ} \mathrm{C}$ to $600{ }^{\circ} \mathrm{C}$ using a heating rate of $10{ }^{\circ} \mathrm{C} \min ^{-1}$.

Temperature Programmed Reduction by Hydrogen $\left(\mathrm{H}_{2}-\mathrm{TPR}\right)$ was realized on a Micromeritics AUTOCHEM 2910 equipped with a TCD detector. Briefly, the aerogel powder $(\mathrm{m}=0.05 \mathrm{~g})$ was pre-treated under $5 \mathrm{vol} \% \mathrm{O}_{2}$ in $\mathrm{He}$ (flow rate $\left.=30 \mathrm{~mL} \mathrm{~min}^{-1}\right)$ at $500{ }^{\circ} \mathrm{C}\left(\operatorname{ramp~} 10{ }^{\circ} \mathrm{C} \mathrm{min}^{-1}\right)$ for $30 \mathrm{~min}$. After being cooled down to $50{ }^{\circ} \mathrm{C}$ in the same atmosphere, the sample was flushed with $\mathrm{He}\left(30 \mathrm{~mL} \mathrm{~min}^{-1}\right)$ then exposed to a flow containing 5 vol $\% \mathrm{H}_{2}$ in $\operatorname{Ar}\left(30 \mathrm{~mL} \mathrm{~min}^{-1}\right)$ and heated between 50 and $800{ }^{\circ} \mathrm{C}\left(10{ }^{\circ} \mathrm{C} \mathrm{min}^{-1}\right)$.

The selective Catalytic Reduction (SCR) tests over the powder aerogel catalysts were carried out in a fixed-bed quartz flow reactor operating at atmospheric pressure. The reaction conditions were controlled as follows: $400 \mathrm{ppm} \mathrm{NO}, 400 \mathrm{ppm} \mathrm{NH}_{3}, 8 \% \mathrm{O}_{2}$ in $\mathrm{He}$ as a balance gas and $100 \mathrm{~mL} \mathrm{~min}^{-1}$ total flow rate yielding a gas hourly space velocity (GHSV) of $120,000 \mathrm{~h}^{-1}$. Before measurements, the catalyst $(0.05 \mathrm{~g})$ was activated in situ at $200{ }^{\circ} \mathrm{C}$ for 30 min under $\mathrm{O}_{2} / \mathrm{He}\left(20 / 80\right.$, v/v) flow then cooled to $100{ }^{\circ} \mathrm{C}$. Afterward, the $\mathrm{NO}$ conversion curves were recorded between 100 and $500{ }^{\circ} \mathrm{C}$ with the heating rate of $6{ }^{\circ} \mathrm{C} \mathrm{min}{ }^{-1}$. The reactants and products gases were continuously analyzed by an online Pfeiffer Omnistar quadruple mass gas spectrometer equipped with Channeltron and Faraday detectors (0-200 amu).

\section{Results and discussion}

\section{1. Textural properties of aerogel catalysts}


The $\mathrm{N}_{2}$ adsorption-desorption isotherms at $77 \mathrm{~K}$ and pores size distribution curves of samples, are illustrated in Fig. $1 \mathrm{~A}$ and $1 \mathrm{~B}$, respectively. As it can be seen, the isotherms of all the catalysts belong to type IV which is typical of mesoporous materials according to the IUPAC classification [33]. The hysteresis loops of $\mathrm{TiO}_{2}$ and $\mathrm{Mn}-\mathrm{TiO}_{2}-\mathrm{SO}_{4}{ }^{2-}$ correspond to $\mathrm{H} 2$ type, indicating, based on the literature reports [34-36], the presence of inkbottle pores. However, the $\mathrm{H} 1$ type, obtained for $\mathrm{Mn}-\mathrm{TiO}_{2}, \mathrm{Ce}-\mathrm{Mn}-\mathrm{TiO}_{2}$ and $\mathrm{Ce}-\mathrm{Mn}-\mathrm{TiO}_{2}-\mathrm{SO}_{4}{ }^{2-}$ systems, reveals, in agreement with similar previous results [37-38], the presence of cylindrical mesoporous channels. On the other hand, the curves displayed in Fig. 1B demonstrate that all the solids are characterized by a unimodal pores distribution with a medium average pore diameter $<200 \AA$. 

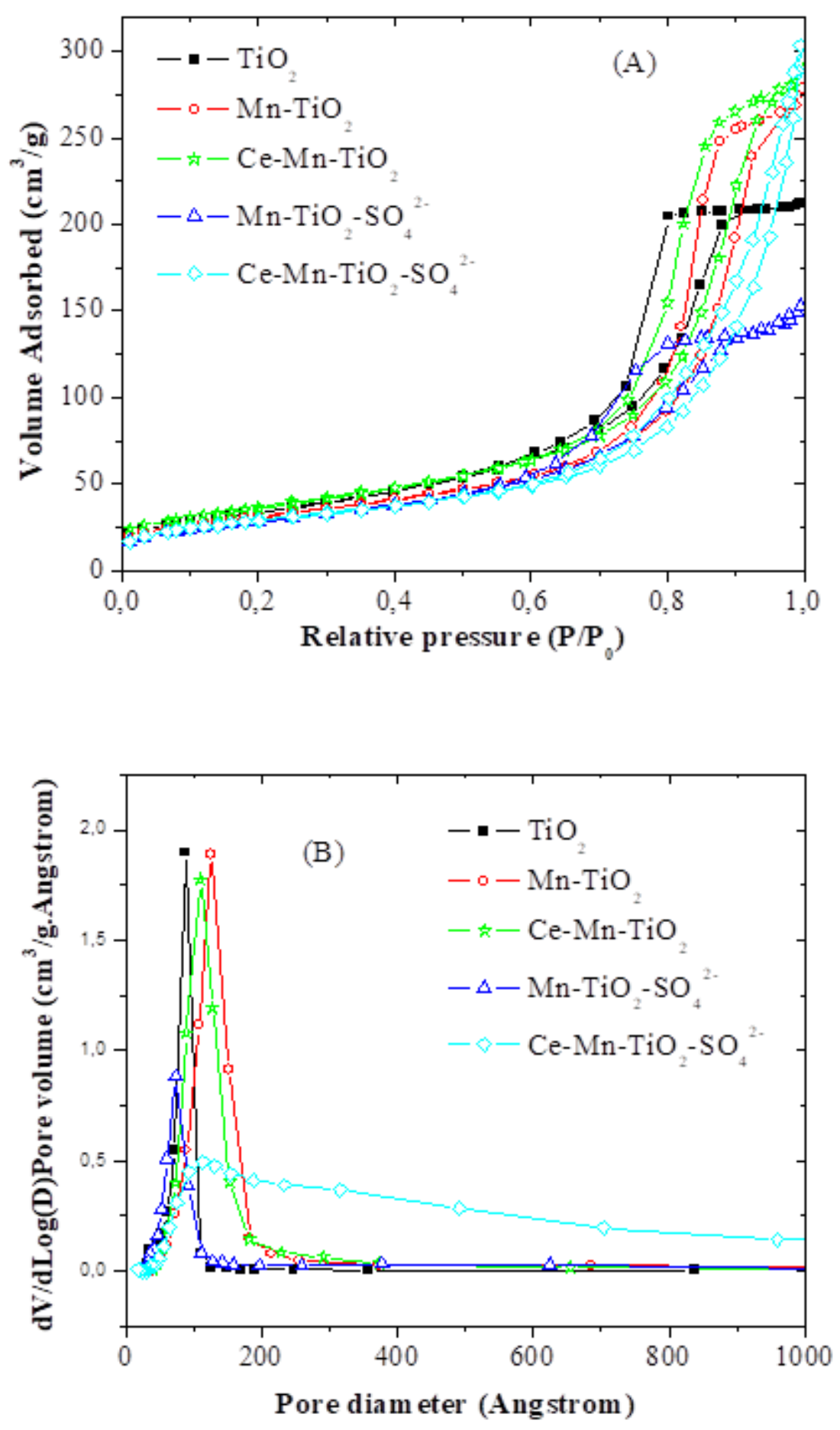

Figure 1. (A) $\mathrm{N}_{2}$ Adsorption-desorption isotherms and (B) Pore size distribution curves of nanostructured mesoporous aerogel catalysts. 
As the catalytic reactions take place on the surface, a high surface area of catalyst can stabilize the supported active phases and consequently provides more active sites for heterogeneous catalytic reactions [2]. The $\mathrm{N}_{2}$ physisorption results listed in table 1 , show that all the aerogel catalysts calcined at $500{ }^{\circ} \mathrm{C}$ exhibit a high surface area $\left(104 \leq \mathrm{S}_{\mathrm{BET}} \leq 132 \mathrm{~m}^{2} / \mathrm{g}\right)$ and large porosity $\left(0.24 \leq \mathrm{V}_{\mathrm{PT}} \leq 0.47\right)$ revealing their developed texture and high thermo-stability. This highlights the appropriate choice of the preparation method (sol-gel proceduresupercritical drying) for adjusting the textural properties of the final aerogel products used as catalytic systems. In fact, it is recognized that large specific surface area implies more active sites exposed on the surface of catalyst and more contact opportunities with gas molecules, which can promote the SCR activity [28].

Table 1. Textural properties of nanostructured mesoporous aerogel catalysts.

\begin{tabular}{lccc}
\hline Sample & $\begin{array}{c}\text { BET surface } \\
\text { area }\left(\mathrm{m}^{2} / \mathrm{g}\right)\end{array}$ & $\begin{array}{c}\text { Total pore } \\
\text { volume }\left(\mathrm{cm}^{3} / \mathrm{g}\right)\end{array}$ & $\begin{array}{c}\text { Average Pore } \\
\text { diameter }\left(\Phi_{\text {pore }}, \AA\right)\end{array}$ \\
\hline $\mathrm{TiO}_{2}$ & 122 & 0.33 & 79 \\
$\mathrm{Mn}-\mathrm{TiO}_{2}$ & 113 & 0.43 & 121 \\
$\mathrm{Mn}-\mathrm{TiO}_{2}-\mathrm{SO}_{4}{ }^{2-}$ & 104 & 0.24 & 75 \\
$\mathrm{Ce}-\mathrm{Mn}-\mathrm{TiO}_{2}$ & 132 & 0.45 & 109 \\
$\mathrm{Ce}-\mathrm{Mn}-\mathrm{TiO}_{2}-\mathrm{SO}_{4}^{2-}$ & 106 & 0.47 & 164 \\
\hline
\end{tabular}

\section{2. Structural properties of aerogel catalysts}

The results of X-ray diffraction analysis are presented in Fig. 2 and table 2. Based on the obtained XRD patterns (Fig. 2), it could be confirmed the successful synthesis of well-structured aerogel materials developing essentially the reflections of $\mathrm{TiO}_{2}$ anatase phase; at $2 \theta \approx 25.3^{\circ}$ (hkl:101); $36.9^{\circ}(103) ; 37.8^{\circ}(004) ; 38.6^{\circ}(112)$; $48.2^{\circ}(200) ; 53.9^{\circ}(105) ; 55.2^{\circ}(211) ; 62.7^{\circ}(204) ; 69.0^{\circ}(116) ; 70.4^{\circ}(220)$ and $75.2^{\circ}(215)$ [ICSD 01-083-2243]. These new aerogel systems are constituted by a nano-cristallites with a size ranging between $\sim 5$ and $9 \mathrm{~nm}$ (table 2). Noting that some weak diffraction peaks, which cannot be attributed to a one type of Mn-oxide, Mn-sulfate and/or Ce-sulfate, are observed in the diffractograms of sulfated samples, in particular, in that of Ce-Mn- $\mathrm{TiO}_{2}-$ $\mathrm{SO}_{4}{ }^{2-}$. The probable formation of the previously cited compounds in a trace amount on $\mathrm{Mn}-\mathrm{TiO}_{2}-\mathrm{SO}_{4}{ }^{2-}$ and $\mathrm{Ce}-$ $\mathrm{Mn}-\mathrm{TiO}_{2}-\mathrm{SO}_{4}{ }^{2-}$ surfaces and their absence in the case of unsulfated solids make evidence about the highly dispersion state of $\mathrm{Mn}$ and Ce species on the catalysts surface. This is consistent with the results already obtained by Know et al. [39]. The authors have showed the absence of characteristic peaks of manganese and cerium oxides in the XRD pattern of Mn/Ce/Ti SCR catalyst, containing 20 wt. \% Mn and 4 wt. \% Ce. 


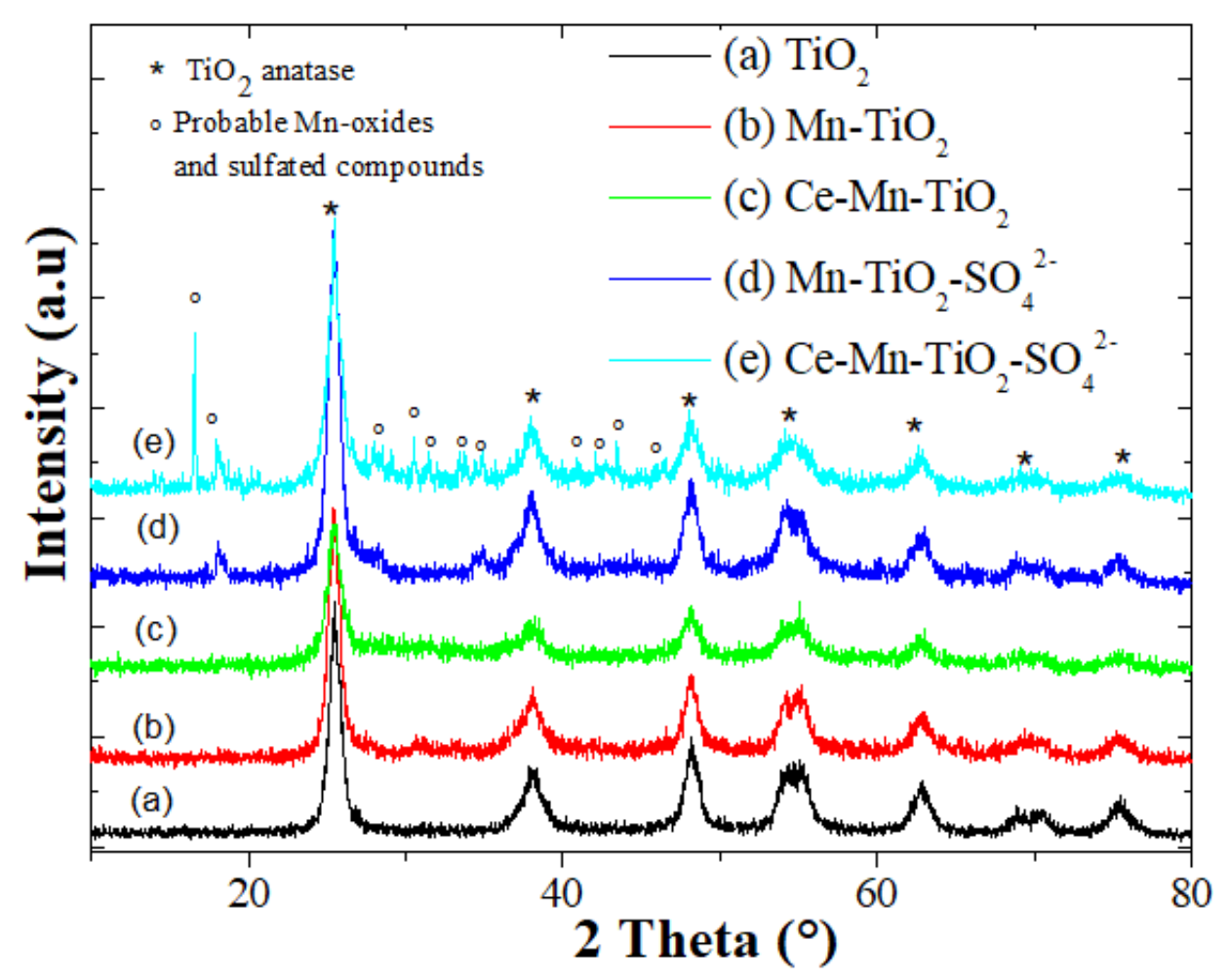

Figure 2. Powder XRD patterns of nanostructured mesoporous aerogel catalysts.

Table 2. XRD phases and $\mathrm{TiO}_{2}$ crystallites size of nanostructured mesoporous aerogel catalysts.

\begin{tabular}{|c|c|c|c|}
\hline Sample & Major XRD phases & FWHM $\left(^{\circ}\right)$ & $\mathrm{TiO}_{2}$ crystallite size $\mathrm{D}(\mathrm{nm})$ \\
\hline $\mathrm{TiO}_{2}$ & Anatase & 0.892 & 8.6 \\
\hline $\mathrm{Mn}-\mathrm{TiO}_{2}$ & Anatase & 0.892 & 8.7 \\
\hline $\mathrm{Mn}-\mathrm{TiO}_{2}-\mathrm{SO}_{4}{ }^{2-}$ & Anatase & 1.106 & 7.0 \\
\hline $\mathrm{Ce}-\mathrm{Mn}-\mathrm{TiO}_{2}$ & Anatase & 0.928 & 8.3 \\
\hline $\mathrm{Ce}-\mathrm{Mn}-\mathrm{TiO}_{2}-\mathrm{SO}_{4}{ }^{2-}$ & Anatase & 1.566 & 4.9 \\
\hline
\end{tabular}

\subsection{Active species characterization}

The valence states of active species had an important impact on the SCR reaction. Diffuse-Reflectance UV-vis spectroscopy was employed to explore the valence states and environment coordination of Ce and Mn species at $\mathrm{TiO}_{2}$ surface. Usually, cerium exhibits two oxidation states $(+3$ and +4$)$ which are characterized by $\mathrm{O}^{2-}$ $\rightarrow \mathrm{Ce}^{3+}$ and $\mathrm{O}^{2-} \rightarrow \mathrm{Ce}^{4+}$ charge transfer bands $(\mathrm{CT})$ in the 220-250 and 280-400 nm range [30], respectively. However, the most common oxidation states of manganese are: $\mathrm{Mn}^{2+}, \mathrm{Mn}^{3+}$ and $\mathrm{Mn}^{4+}$. The charge transfer and d$\mathrm{d}$ transitions of Mn species are identified based on the literature reports and listed in table 3 [40-46]. 
The UV-vis spectra of all the samples (Fig. 3) show the typical absorption bands of $\mathrm{TiO}_{2}$ in the $200-400 \mathrm{~nm}$ range [47]. The increase of the intensity of these bands after Mn and Ce addition can be associated with the absorptions of $\mathrm{Ce}$ (probably $\mathrm{Ce}^{3+}$ and $\mathrm{Ce}^{4+}[30]$ ) and $\mathrm{Mn}$ (mainly $\mathrm{Mn}^{2+}$ and $\mathrm{Mn}^{3+}$ [40-45]) species at the same region than those of titanium. Markedly, a new absorption bands are appeared for $\lambda>400 \mathrm{~nm}$ in the case of Mn$\mathrm{TiO}_{2}$ and $\mathrm{Ce}-\mathrm{Mn}-\mathrm{TiO}_{2}$ samples. The bands located at $\sim 420$ and $550 \mathrm{~nm}$ can be ascribed to $\mathrm{O}^{2-} \rightarrow \mathrm{Mn}^{4+}[40,44,46]$ and new $\mathrm{O}^{2-} \rightarrow \mathrm{Mn}^{3+}[40,41] \mathrm{CT}$ transitions, respectively. Nevertheless, those located at $\lambda \geq 500 \mathrm{~nm}$ can be attributed to d-d transitions of Mn (II and III) [40-42, 46]. Remarkably, these bands disappear after sulfation of catalysts implying that sulfate groups affect extremely the nature of Mn surface species, perhaps due to the existence of strong $\mathrm{Mn}-\mathrm{SO}_{4}{ }^{2-}$ interactions. The formation of manganese sulfate compounds cannot be also excluded in this case.

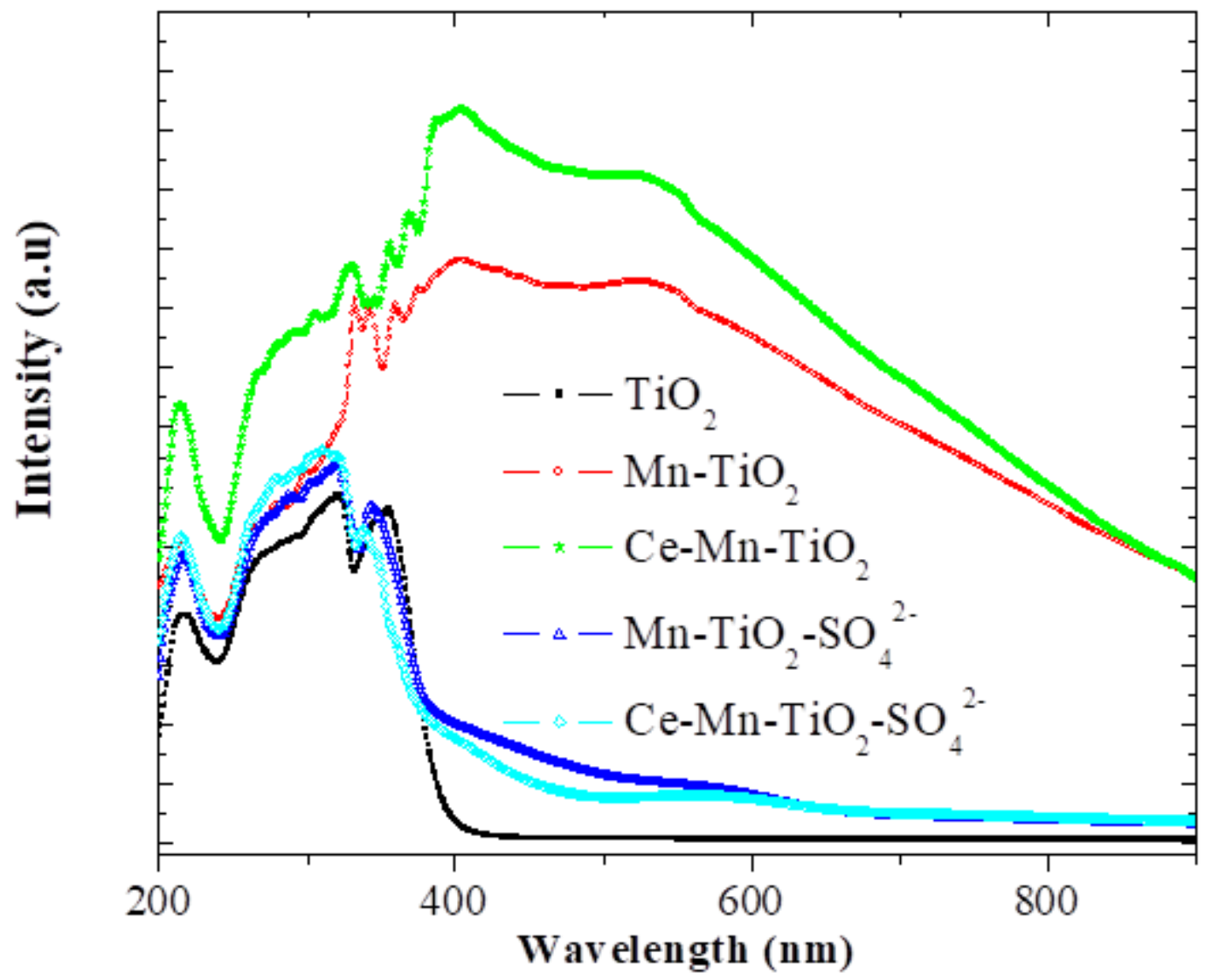

Figure 3. DRUV-Vis spectra of nanostructured mesoporous aerogel catalysts. 
Table 3. Characteristic UV absorption bands $\left(\mathrm{O}^{2-} \rightarrow \mathrm{Mn}^{\mathrm{n}+}\right.$ charge transfer $(\mathrm{CT})$ and d-d) of manganese species.

\begin{tabular}{lllll}
\hline $\mathrm{Mn}^{\mathrm{n}+}$ & Compound/Coordination & $\lambda(\mathrm{nm})$ & Assignment & References \\
\hline $\mathrm{Mn}^{2+}$ & $\mathrm{MnO}$ & $500-610$ & $\mathrm{~d}-\mathrm{d}$ & {$[40-42]$} \\
& $\mathrm{Mn}_{3} \mathrm{O}_{4}$ & 255 & $\mathrm{O}^{2-} \rightarrow \mathrm{Mn}^{2+}$ & {$[42]$} \\
& $\mathrm{Mn}_{3} \mathrm{O}_{4}$ & 500 & $\mathrm{~d}-\mathrm{d}$ & {$[40,41]$} \\
$\mathrm{Mn}^{3+}$ & Tetrahedral coordination & $210-280$ & $\mathrm{O}^{2-} \rightarrow \mathrm{Mn}^{3+}$ & {$[40,43,40]$} \\
& Octahedral coordination & $311-350$ & $\mathrm{O}^{2-} \rightarrow \mathrm{Mn}^{3+}$ & {$[40-45]$} \\
$\mathrm{Mn}^{3+}$ & $\mathrm{Mn}_{2} \mathrm{O}_{3}$ & $450-550$ & $\mathrm{O}^{2-} \rightarrow \mathrm{Mn}^{3+}$ & {$[40,41]$} \\
& & $720-750$ & $\mathrm{~d}-\mathrm{d}$ & {$[42,46]$} \\
$\mathrm{Mn}^{4+}$ & $\mathrm{MnO}_{2}$ & $350-420$ & $\mathrm{O}^{2-} \rightarrow \mathrm{Mn}^{4+}$ & {$[40]$} \\
& & 420 & $\mathrm{O}^{2-} \rightarrow \mathrm{Mn}^{4+}$ & {$[46]$} \\
& $400-500$ & $\mathrm{O}^{2-} \rightarrow \mathrm{Mn}^{4+}$ & {$[44]$} \\
\hline
\end{tabular}

\subsection{Acidity and reducibility of aerogel catalysts}

The acidity and reducibility of catalysts were evaluated by $\mathrm{NH}_{3}$-TPD and $\mathrm{H}_{2}$-TPR techniques. The recorded curves are displayed in Fig. 4 and Fig. 5, respectively.

As shown in Fig. 4, a broad desorption peak is registered from 100 to $400{ }^{\circ} \mathrm{C}$ for all the samples and is assigned to $\mathrm{NH}_{3}$ desorbed from weak and medium acid sites [30,48-50]. The intensity of this peak is higher in the case of the $\mathrm{Mn}-\mathrm{TiO}_{2}$ sample indicating that the addition of manganese improves significantly the surface acidity of catalytic support. This is in agreement with the results previously obtained by You et al. [51]. The authors concluded that the increase of $\mathrm{Mn}$ amount had a positive effect on the acidity of $\mathrm{MnOx}-\mathrm{CeO}_{2} / \mathrm{GR}$ catalysts and contributes greatly to its high NO-SCR by $\mathrm{NH}_{3}$ activity. After sulfation of $\mathrm{Mn}-\mathrm{TiO}_{2}$ catalyst, a new peak belonging to $\mathrm{NH}_{3}$-desorbed from strong acid sites, generated by sulfate groups, has appeared at high temperature $\sim 500{ }^{\circ} \mathrm{C}$ [30,31]. It should be mentioned that the addition of cerium induces a decrease of the total acidity (mainly medium and strong ones) of the unsulfated and sulfated Mn based solids. This could be explained by the existence of Mn$\mathrm{Ce}$ and $\mathrm{Ce}-\mathrm{SO}_{4}{ }^{2-}$ interactions which inhibits some acidic sites of catalysts. 


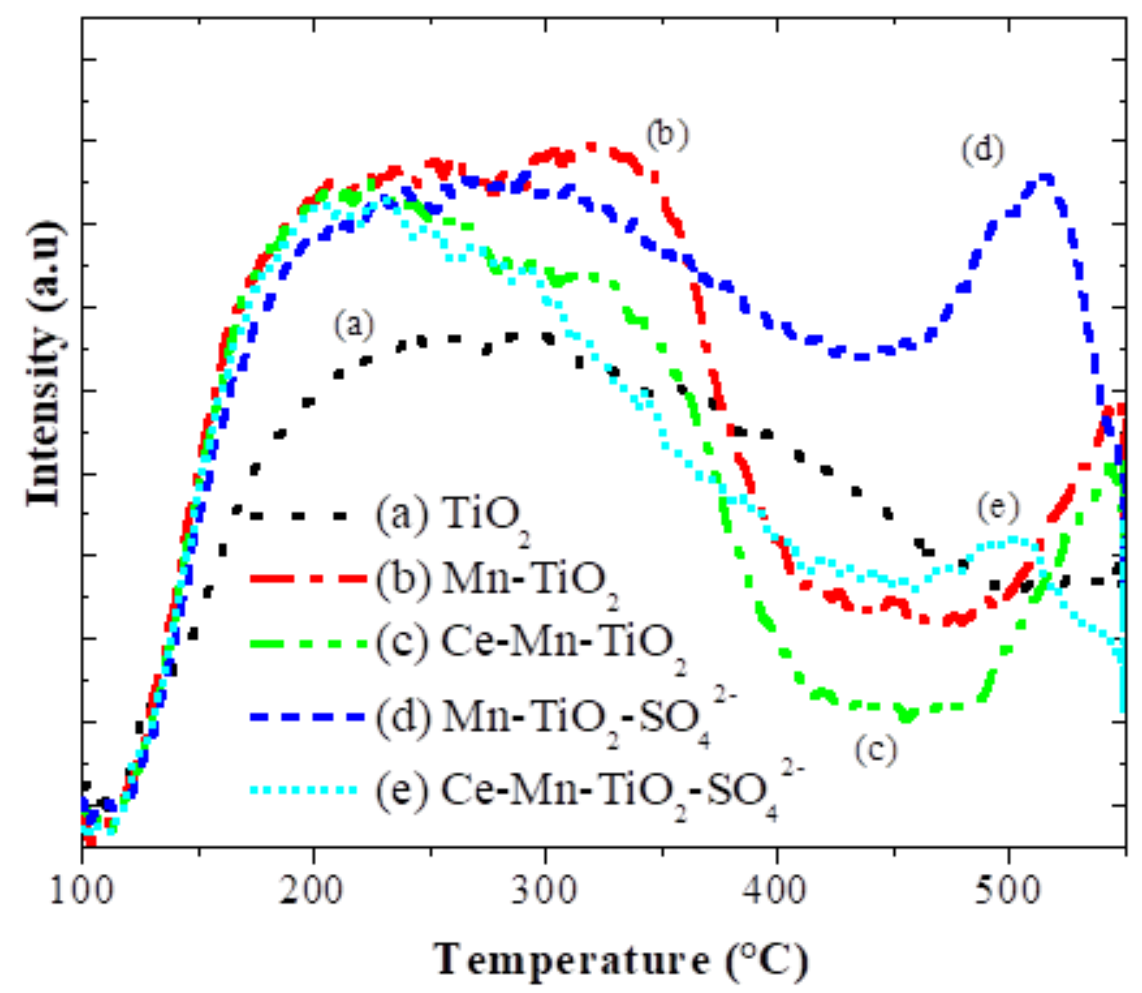

Figure 4. $\mathrm{NH}_{3}$-TPD profiles of nanostructured mesoporous aerogel catalysts.

As illustrated in Fig. 5, the $\mathrm{H}_{2}-\mathrm{TPR}$ profile of $\mathrm{Mn}-\mathrm{TiO}_{2}$ catalyst shows a single hydrogen consumption peak centered at around $290{ }^{\circ} \mathrm{C}$ with a shoulder at $\sim 434{ }^{\circ} \mathrm{C}$. According to the literature, the major peak is related to the reduction of surface $\mathrm{MnO}_{2}$ to $\mathrm{Mn}_{2} \mathrm{O}_{3}$, while, the shoulder can be ascribed to the reduction of surface $\mathrm{Mn}_{2} \mathrm{O}_{3}$ to $\mathrm{Mn}_{3} \mathrm{O}_{4}$ [39]. This means that $\mathrm{Mn}^{4+}$ species are the most predominant species of manganese at $\mathrm{Mn}^{-} \mathrm{TiO}_{2}$ surface. For Ce-Mn- $\mathrm{TiO}_{2}$ system, the peak was shifted to higher temperature $\left(\sim 325^{\circ} \mathrm{C}\right)$ and its area slightly increases revealing the reduction of manganese at higher temperature in the presence of cerium species. These species seem to be reduced at the same temperature range than manganese and affects its reducibility. The addition of sulfate completely hidden the reduction of other species, since, only one intense peak, corresponding to the reduction of sulfate groups, is detected at $\sim 620{ }^{\circ} \mathrm{C}[30,31,52]$ in the $\mathrm{H}_{2}$-TPR profiles of sulfated aerogel catalysts. It is worth noting that the intensity of the peak attributed to the reduction of $\mathrm{SO}_{4}{ }^{2-}$ groups is higher in the case of Ce-Mn$\mathrm{TiO}_{2}-\mathrm{SO}_{4}{ }^{2-}$ catalyst compared to that of $\mathrm{Mn}-\mathrm{TiO}_{2}-\mathrm{SO}_{4}{ }^{2-}$ sample. This can confirm, in line with the UV-vis and $\mathrm{NH}_{3}-$ TPD results, the existence of strong interactions $\mathrm{Mn}-\mathrm{SO}_{4}{ }^{2-}$ which most likely affects the nature and oxidation state of Mn species, the dispersion degree of sulfate groups and thereby the NO-SCR activity of the new aerogel catalysts. 

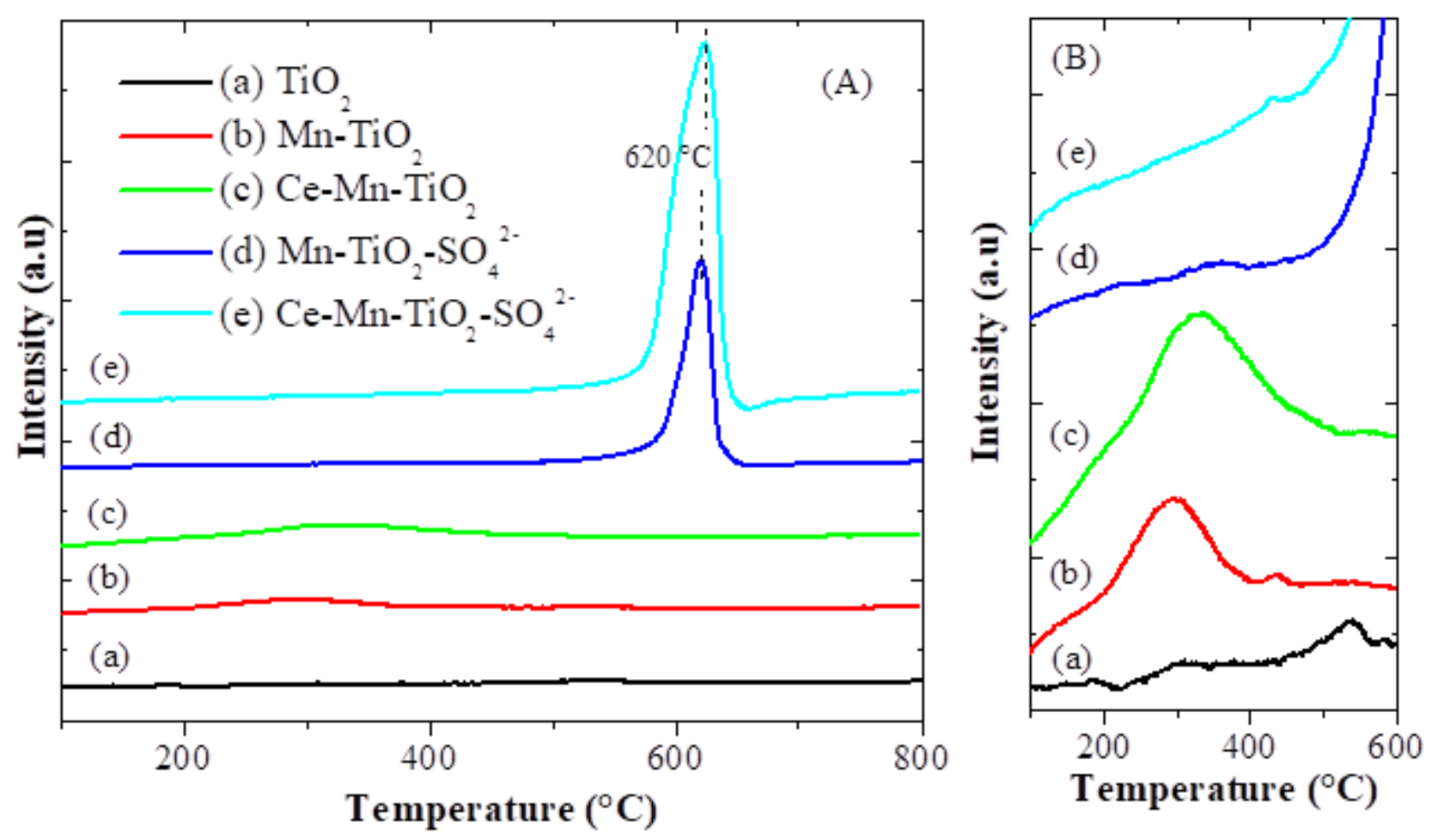

Figure 5. $\mathrm{H}_{2}$-TPR profiles of nanostructured mesoporous aerogel catalysts.

\section{5. SCR performance evaluation}

The NO-SCR activity of catalysts were measured as function of temperature and the products were analyzed by a quadruple mass gas spectrometer. It is worth mentioning that $\mathrm{N}_{2} \mathrm{O}$ was the major product detected over the unsufated samples. Nevertheless, the sulfated catalysts are completely selective into $\mathrm{N}_{2}$.

Fig. 6 shows the NO conversion versus reaction temperature over all the aerogel catalysts. It is clearly seen that $\mathrm{TiO}_{2}$ support is inactive in the low temperature NO-SCR by $\mathrm{NH}_{3}\left(\mathrm{~T}<300{ }^{\circ} \mathrm{C}\right)$ and exhibits a maximum of $\sim 50 \% \mathrm{NO}$ conversion into $\mathrm{N}_{2}$ at $500{ }^{\circ} \mathrm{C}$. By contrast, above $75 \%$ of $\mathrm{NO}$ conversions into essentially $\mathrm{N}_{2} \mathrm{O}$ are obtained, in the $150-270{ }^{\circ} \mathrm{C}$ temperature range, over $\mathrm{Mn}-\mathrm{TiO}_{2}$ catalyst. The high catalytic behaviour of this aerogel catalyst in reducing $\mathrm{NO}$ into $\mathrm{N}_{2} \mathrm{O}$ can be correlated with the predominance of $\mathrm{Mn}^{4+}$ species at its surface, as suggested from the $\mathrm{H}_{2}-\mathrm{TPR}$ and UV-vis results. In fact, it is established that $\alpha-\mathrm{Mn}_{2} \mathrm{O}_{3}$ is preferred for SCR reaction due to its high selectivity toward $\mathrm{N}_{2}$ formation. In addition, Liu et al. [26] reported that $\beta-\mathrm{MnO}_{2}$ with lower $\mathrm{Mn}-\mathrm{O}$ bond energy compared to $\alpha-\mathrm{Mn}_{2} \mathrm{O}_{3}$, can cleave more $\mathrm{N}-\mathrm{H}$ bonds under $\mathrm{NH}_{3}$ to form more $\mathrm{N}$-species, resulting in higher selectivity to $\mathrm{N}_{2} \mathrm{O}$. Moreover, Tang et al. [53] showed that higher $\mathrm{NO}$ conversion and $\mathrm{N}_{2} \mathrm{O}$ selectivity are achieved over $\beta-\mathrm{MnO}_{2}$ with respect to $\alpha-\mathrm{Mn}_{2} \mathrm{O}_{3}$. The addition of cerium slightly increases the NO conversion at 
low temperatures which imply that, in this case, manganese are the most active species and their reactivity, in converting $\mathrm{NO}$ to $\mathrm{N}_{2} \mathrm{O}$, is slightly affected by the presence of cerium. For these two catalysts, the strong drop of NO conversion above $280^{\circ} \mathrm{C}$ is due to the ammonia oxidation side reaction. Conversely, the sulfation of catalysts strongly affects their catalytic performances in the NO-SCR reaction. It induces a substantial decrease of the NO conversion at low temperatures (NO conversion $<9 \%$ below $300{ }^{\circ} \mathrm{C}$ ) but improves obviously the high temperatures SCR activity (NO conversion and $\mathrm{N}_{2}$ - selectivity) of sulfated $\mathrm{Mn}-\mathrm{TiO}_{2}-\mathrm{SO}_{4}{ }^{2-}$ and $\mathrm{Ce}-\mathrm{Mn}-\mathrm{TiO}_{2}-\mathrm{SO}_{4}{ }^{2-}$ catalysts. These systems exhibit approximately a similar catalytic behavior and above $90 \%$ NO conversions into $\mathrm{N}_{2}(100 \%)$ are achieved, between 450 and $500{ }^{\circ} \mathrm{C}$, over the Ce-Mn- $\mathrm{TiO}_{2}-\mathrm{SO}_{4}{ }^{2-}$ aerogel catalyst (Table 4). Noting that, the substantial decrease of the NO conversion at low temperatures accompanied by its notable increase (into $\mathrm{N}_{2}$ ) at higher temperatures, observed with sulfate addition, may be attributed to (i) the change of the nature of manganese species, mostly the oxidation state (from $\mathrm{Mn}^{4+}$ to other forms), which is mainly due to existence of strong interactions $\mathrm{Mn}_{-} \mathrm{SO}_{4}{ }^{2-}$, as it was revealed by UV-vis and $\mathrm{H}_{2}$-TPR techniques, and (ii) the creation of new strong acid sites able to retain $\mathrm{NH}_{3}$ adsorbed at high temperature, as it was showed by $\mathrm{NH}_{3}-\mathrm{TPD}$ analysis. In fact, in NO-SCR by $\mathrm{NH}_{3}$, it is admitted that $\mathrm{NH}_{4}{ }^{+}$adsorbed on the Brönsted acid sites plays a major role in $\mathrm{NH}_{3}-\mathrm{SCR}$ reaction at high temperature [9].

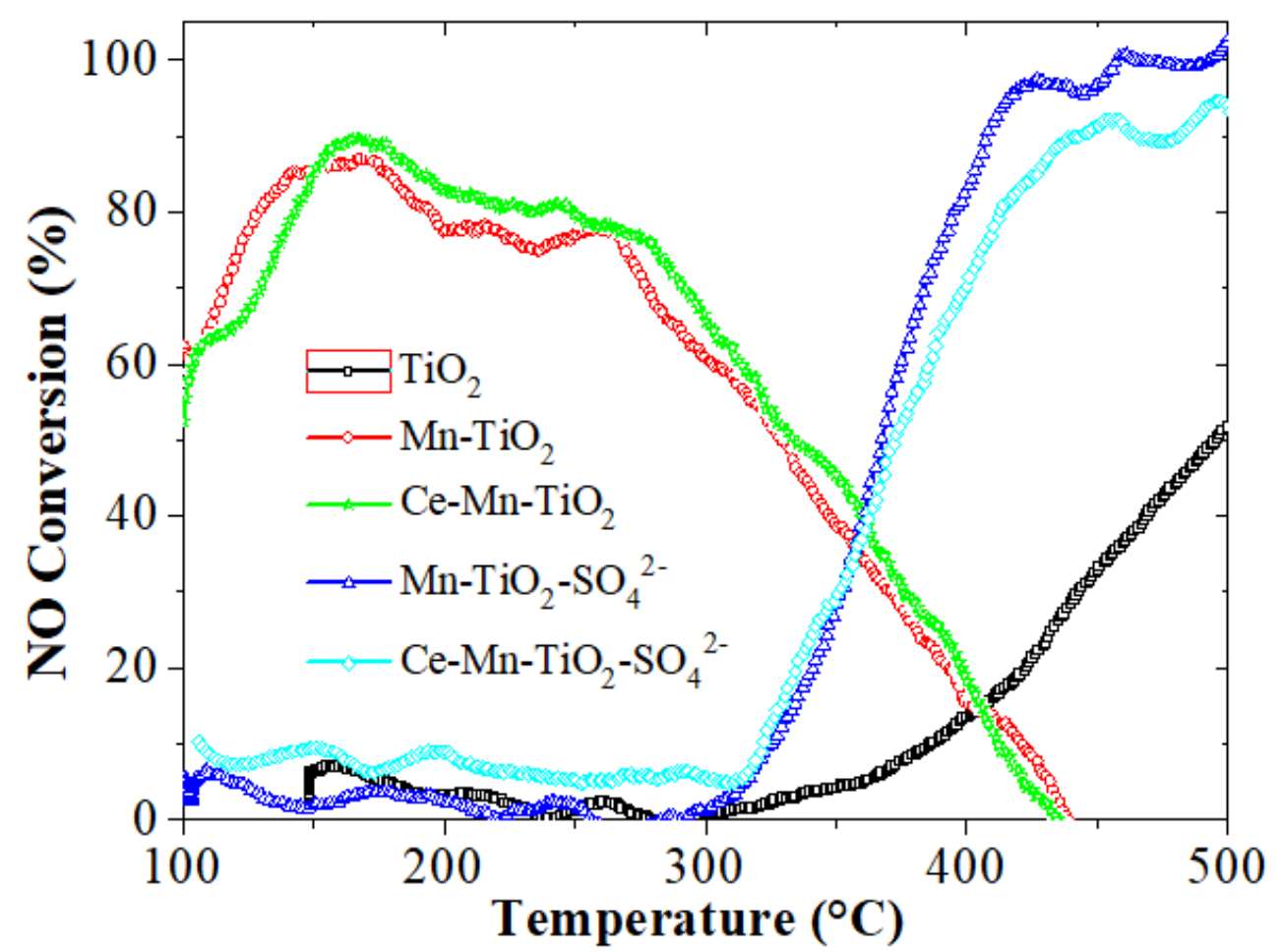

Figure 6. NO removal efficiencies over the nanostructured mesoporouserogel catalysts: $[\mathrm{NO}]=\left[\mathrm{NH}_{3}\right]$ $=0.04 \% ;\left[\mathrm{O}_{2}\right]=8.00 \%$ and balance with $\mathrm{He},(\mathrm{GHSV})=120000 \mathrm{~h}^{-1}$. 
Table 4. Catalytic behaviour of $\mathrm{Mn}-\mathrm{TiO}_{2}-\mathrm{SO}_{4}{ }^{2-}$ and $\mathrm{Ce}-\mathrm{Mn}-\mathrm{TiO}_{2}-\mathrm{SO}_{4}{ }^{2-}$ nanostructured mesoporous aerogel catalysts calcined at $500{ }^{\circ} \mathrm{C}$ in NO-SCR by $\mathrm{NH}_{3}:[\mathrm{NO}]=\left[\mathrm{NH}_{3}\right]=0.04 \%,\left[\mathrm{O}_{2}\right]=8.00 \%$ balance with He and $(G H S V)=120000 h^{-1}$.

\begin{tabular}{|c|c|c|c|c|c|}
\hline \multirow[t]{2}{*}{ Aerogel catalyst } & \multirow[t]{2}{*}{$\begin{array}{c}\text { Temperature } \\
\left({ }^{\circ} \mathrm{C}\right)\end{array}$} & \multirow[t]{2}{*}{$\begin{array}{c}\text { NO Conversion } \\
(\%)\end{array}$} & \multicolumn{3}{|c|}{$\begin{array}{c}\text { Selectivity } \\
(\%)\end{array}$} \\
\hline & & & $\mathrm{N}_{2}$ & $\mathrm{~N}_{2} \mathrm{O}$ & $\mathrm{NO}_{2}$ \\
\hline \multirow[t]{7}{*}{$\mathrm{Mn}-\mathrm{TiO}_{2}-\mathrm{SO}_{4}{ }^{2-}$} & 200 & 2 & 100 & 0 & 0 \\
\hline & 250 & 2 & 100 & 0 & 0 \\
\hline & 300 & 2 & 100 & 0 & 0 \\
\hline & 350 & 28 & 100 & 0 & 0 \\
\hline & 400 & 82 & 100 & 0 & 0 \\
\hline & 450 & 97 & 100 & 0 & 0 \\
\hline & 500 & 100 & 95 & 5 & 0 \\
\hline \multirow[t]{7}{*}{$\mathrm{Ce}-\mathrm{Mn}-\mathrm{TiO}_{2}-\mathrm{SO}_{4}{ }^{2-}$} & 200 & 9 & 100 & 0 & 0 \\
\hline & 250 & 5 & 100 & 0 & 0 \\
\hline & 300 & 6 & 100 & 0 & 0 \\
\hline & 350 & 30 & 100 & 0 & 0 \\
\hline & 400 & 70 & 100 & 0 & 0 \\
\hline & 450 & 91 & 100 & 0 & 0 \\
\hline & 500 & 93 & 100 & 0 & 0 \\
\hline
\end{tabular}

\section{Conclusion}

In this study, a new series of nanostructured and mesoporous Mn-based catalysts were successfully prepared via the sol gel method combined to supercritical drying for the NO-SCR by $\mathrm{NH}_{3}$ in a wide temperature range $\left(100-500{ }^{\circ} \mathrm{C}\right)$, under a high GHSV $\left(120000 \mathrm{~h}^{-1}\right)$. The results reveal that all the obtained aerogel catalysts $\left(\mathrm{Mn}-\mathrm{TiO}_{2}, \mathrm{Ce}-\mathrm{Mn}-\mathrm{TiO}_{2}, \mathrm{Mn}-\mathrm{TiO}_{2}-\mathrm{SO}_{4}{ }^{2-}\right.$ and $\left.\mathrm{Ce}-\mathrm{Mn}-\mathrm{TiO}_{2}-\mathrm{SO}_{4}{ }^{2-}\right)$ show a developed texture with a good cristallinity of $\mathrm{TiO}_{2}$ anatase phase. $\mathrm{Mn}, \mathrm{Ce}$ and $\mathrm{SO}_{4}{ }^{2-}$ were found highly dispersed on the catalyst surfaces and their presence extremely influences the physicochemical and catalytic properties of aerogel solids. $\mathrm{Mn}-\mathrm{TiO}_{2}$ and Ce$\mathrm{Mn}-\mathrm{TiO}_{2}$ systems display high $\mathrm{NO}$ conversions into $\mathrm{N}_{2} \mathrm{O}$ at low temperatures, which was correlated with the predominance of $\mathrm{Mn}^{4+}$ form on their surface. The addition of sulfate modifies the nature of $\mathrm{Mn}$ species, acidity and reducibility of Mn-based catalysts and strongly affects their NO-SCR reactivity. High NO conversions into $\mathrm{N}_{2}$ (above $90 \%$ ) are obtained at high temperature over the suflated catalysts. 


\section{There are no conflicts of interest to declare}

\section{Acknowledgements}

The authors wish to express their sincere thanks to Thomas Cacciaguerra for XRD analysis. Financial support by Laboratory of Chemistry of Materials and Catalysis (LCMC) of Tunisia and FrancoTunisian Cooperation (French Institute of Tunisia, SSHN grant) are gratefully acknowledged.

\section{References}

[1] Maleki H, (2016) Recent advances in aerogels for environmental remediation applications. A review Chem Eng J 300: 98-118

[2] Maleki H, Hüsing N, (2018) Current status, opportunities and challenges in catalytic and photocatalytic applications of aerogels: Environmental protection aspects. Appl Catal B Environ 221: 530-555

[3] Li J, Chang H, Ma L, Hao J, Yang RT (2011) Low-temperature selective catalytic reduction of NOx with $\mathrm{NH}_{3}$ over metal oxide and zeolite catalysts A Review Catal Today 175: 147-156.

[4] Boningari T, Koirala R, Smirniotis PG, (2012) Low-temperature selective catalytic reduction of $\mathrm{NO}_{\text {with }} \mathrm{NH}_{3}$ over $\mathrm{V} / \mathrm{ZrO}_{2}$ prepared by flame-assisted spray pyrolysis: Structural and catalytic properties. Appl Catal B Environ 127: $255-64$.

[5] Liu BT, Huang CJ, Ke YX, Wang WH., Kuo HL, Lin D, Lin V, Lin SH, (2017) Enhanced selective catalytic reduction of $\mathrm{NO}$ over $\mathrm{Mn}-\mathrm{Ce}$ catalysts with the acetic-acid-chelated titania support at low temperature. Appl Catal A Gen 538: 74-80.

[6] Nam KB, Kwon DW, Hong S C, (2017) DRIFT study on promotion effects of tungsten-modified Mn/Ce/Ti catalysts for the SCR reaction at low-temperature. Appl Catal A Gen 542: 55-62.

[7] Damma D, Ettireddy PR, Reddy BM, Smirniotis PG, (2019) A Review of Low Temperature $\mathrm{NH}_{3}-\mathrm{SCR}$ for Removal of NOx. Catalysts 9: 349-384.

[8] Gholami F, Tomas M, Gholami Z, Vakili M, (2020) A Review Technologies for the nitrogen oxides reduction from flue gas. Sci Total Environ 714 :136712-136738

[9] Gao F, Tang X, Yi H, Zhao S, Li C, Li J, Shi Y, Meng X, (2017) A Review on Selective Catalytic Reduction of NOx by $\mathrm{NH}_{3}$ over Mn-Based Catalysts at Low Temperatures, Mechanisms, Kinetics and DFT Calculations. Catalysts 7: 199-231.

[10] Deng SC, Meng TT, Xu BL, Gao F, Ding Y H, Yu L, Fan YN, (2016) Advanced $\mathrm{MnO}_{x} / \mathrm{TiO}_{2}$ Catalyst with Preferentially Exposed Anatase \{001\} Facet for Low-Temperature SCR of NO, ACS catal. 6 : 5807-5815. 
[11] Yao X, Kong T, Chen L, Ding S, Yang F, Dong L, (2017) Enhanced low-temperature $\mathrm{NH}_{3}-\mathrm{SCR}$ performance of $\mathrm{MnOx} / \mathrm{CeO}_{2}$ catalysts by optimal solvent effect. App Surf Sci 420 : 407-415.

[12] Kijlstra WS, Biervliet M, Poels EK, Bliek A, (1998) Deactivation by $\mathrm{SO}_{2}$ of $\mathrm{MnO}_{x} / \mathrm{Al}_{2} \mathrm{O}_{3}$ catalysts used for the selective catalytic reduction of $\mathrm{NO}$ with $\mathrm{NH}_{3}$ at low temperatures. Appl Catal B Environ 16: 327-337.

[13] Lou XR, Liu PF, Li J, Li Z, He K, (2014) Effects of calcination temperature on Mn species and catalytic activities of Mn/ZSM-5 catalyst for selective catalytic reduction of NO with ammonia. Appl Surf Sci 307: 382387.

[14] Xu W, Zhang G, Chen H, Zhang G, Han Y, Chang Y, Gong P, (2018) Mn/beta and Mn/ZSM-5 for the lowtemperature selective catalytic reduction of NO with ammonia: Effect of manganese precursors. Chinese J Catal 39: $118-127$.

[15] Su Y, Fan B, Wang L, Liu Y, Huang B, Fu M, Chen L, Ye D, (2013) $\mathrm{MnO}_{\mathrm{x}}$ supported on carbon nanotubes by different methods for the SCR of NO with $\mathrm{NH}_{3}$. Catal Today 201: 115-121.

[16] Peña DA, Uphade BS, Smirniotis PG, (2004) $\mathrm{TiO}_{2}$-supported metal oxide catalysts for low-temperature selective catalytic reduction of $\mathrm{NO}$ with $\mathrm{NH}_{3}$ : I. Evaluation and characterization of first row transition metals. J Catal 221: 421-431.

[17] Smirniotis PG, Sreekanth PM, Peña DA, Jenkins RG, (2006) Manganese Oxide Catalysts Supported on $\mathrm{TiO}_{2}$, $\mathrm{Al}_{2} \mathrm{O}_{3}$, and $\mathrm{SiO}_{2}$ : A Comparison for Low-Temperature SCR of NO with $\mathrm{NH}_{3}$, Ind. Eng. Chem. Res. 45 : 64366443.

[18] Wu ZB, Jin RB, Liu Y, Wang HQ, (2008) Ceria modified $\mathrm{MnO}_{\mathrm{x}} / \mathrm{TiO}_{2}$ as a superior catalyst for NO reduction with $\mathrm{NH}_{3}$ at low-temperature. Catal Commun 9:2217-2220.

[19] Wu ZB, Jin RB, Wang HQ, Liu Y, (2009) Effect of ceria doping on $\mathrm{SO}_{2}$ resistance of $\mathrm{Mn} / \mathrm{TiO}_{2}$ for selective catalytic reduction of $\mathrm{NO}$ with $\mathrm{NH}_{3}$ at low temperature. Catal Commun 10: 935-939.

[20] Sheng ZY, Hu YF, Xue JM, Wang XM, Liao WP, (2012) $\mathrm{SO}_{2}$ poisoning and regeneration of $\mathrm{Mn}-\mathrm{Ce} / \mathrm{TiO}{ }_{2}$ catalyst for low temperature $\mathrm{NO}_{x}$ reduction with $\mathrm{NH}_{3}$, J. Rare Earths 30: 676-682.

[21] Sheng ZY, Hu YF, Xue JM, Wang XM, Liao WP, (2012) A novel co-precipitation method for preparation of $\mathrm{Mn}-\mathrm{Ce} / \mathrm{TiO}_{2}$ composites for $\mathrm{NO}_{\mathrm{x}}$ reduction with $\mathrm{NH}_{3}$ at low temperature. Environ. Technol. 33:2421-2428.

[22] Zhou A, Yu D, Yang L, Sheng Z, (2016) Combined effects $\mathrm{Na}$ and $\mathrm{SO}_{2}$ in flue gas on $\mathrm{Mn}-\mathrm{Ce} / \mathrm{TiO}{ }_{2}$ catalyst for low temperature selective catalytic reduction of $\mathrm{NO}$ by $\mathrm{NH}_{3}$ simulated by $\mathrm{Na}_{2} \mathrm{SO}_{4}$ doping. Appl Surf Sci 378 : $167-173$. 
[23] Wu ZB, Jiang BQ, Liu Y, Zhao WR, Guan BH, (2007) Experimental study on a low-temperature SCR catalyst based on $\mathrm{MnO}_{\mathrm{x}} / \mathrm{TiO}_{2}$ prepared by sol-gel method. J Hazard Mater 145: 488-494.

[24] Tang C, Zhang H, Dong L, (2016) Ceria-based catalysts for low-temperature selective catalytic reduction of NO with $\mathrm{NH}_{3}$. Catal Sci Technol 6:1248-1264.

[25] Xu H, Liu S, Wang Y, Lin Q, Lin C, Lan L, Wang Q, Chen Y, (2018) Promotional effect of $\mathrm{Al}_{2} \mathrm{O}_{3}$ on $\mathrm{WO}_{3} / \mathrm{CeO}_{2}-\mathrm{ZrO}_{2}$ monolithic catalyst for selective catalytic reduction of nitrogen oxides with ammonia after hydrothermal aging treatment. Appl Surf Sci 427: 656-669.

[26] Liu C, Shi JW, Gao C, Niu C, (2016) Manganese oxide-based catalysts for low-temperature selective catalytic reduction of NOx with $\mathrm{NH}_{3}$ A review. Appl Catal A Gen 522: 54-69.

[27] Kapteijn F, Singoredjo L, Andreini A, Moulijn JA, (1994) Activity and selectivity of pure manganese oxides in the selective catalytic reduction of nitric oxide with ammonia. Appl Catal B Environ. 3: 173-169

[28] Kang M, Yeon TH, Park ED, Yie JE, Kim JM, (2006) Novel $\mathrm{MnO}_{x}$ Catalysts for NO Reduction at Low Temperature with Ammonia. Catal Lett 106: 77-80.

[29] Engweiler J, Baiker A, (1994) Vanadia supported on titania aerogels-morphological properties and catalytic behaviour in the selective reduction of nitric-oxide by ammonia. Appl Catal A Gen 120:187-205.

[30] Arfaoui J, Ghorbel A, Petitto C, Delahay G, (2018) Novel $\mathrm{V}_{2} \mathrm{O}_{5}-\mathrm{CeO}_{2}-\mathrm{TiO}_{2}-\mathrm{SO}_{4}{ }^{2-}$ nanostructured aerogel catalyst for the low temperature selective catalytic reduction of $\mathrm{NO}_{\text {by }} \mathrm{NH}_{3}$ in excess $\mathrm{O}_{2}$. Appl Catal B Environ 224: $264-275$.

[31] Arfaoui J, Ghorbel A, Petitto C, Delahay G, (2020) A new $\mathrm{V}_{2} \mathrm{O}_{5}-\mathrm{MoO}_{3}-\mathrm{TiO}_{2}-\mathrm{SO}_{4}{ }^{2-}$ nanostructured aerogel catalyst for Diesel DeNOx technology. New J Chem 44: 16119-16134.

[32] Noreen Z, Khalid NR, Abbasi R, Javed S , Ahmad I, Bokhari H, (2019) Visible light sensitive $\mathrm{Ag} / \mathrm{TiO}_{2} / \mathrm{graphene}$ composite as a potential coating material for control of Campylobacter jejuni. Mater Sci Eng C $98: 125-133$.

[33] IUPAC (1985) Reporting physisorption data for gas/solid systems with special reference to the determination of surface area and porosity. Pure Appl Chem 57: 603-619.

[34] Lopez T, Rojas F, Katz RA, Galindo F, Balankin A, Buljanc A, (2004) Porosity, structural and fractal study of sol-gel $\mathrm{TiO}_{2}-\mathrm{CeO}_{2}$ mixed oxides, J. Solid. State Chem. 177:1873-1885.

[35] Morishige K, Tateishi N, (2003) Adsorption hysteresis in ink-bottle pore J Chem Phys 119: 2301-2306. [36] Nguyen PT, Fan C, Do D, Nicholson D, (2013) On the cavitation-like pore blocking in ink-bottle pore: evolution of hysteresis loop with neck size. J. Phys. Chem. C 117: 5475-5484. 
[37] López-Mendoza MA, Nava R, Peza-Ledesma C, Millán-Malo B, Huirache-Acuña R, Skewes, Rivera-Muñoz

EM, (2016) Characterization and catalytic performance of Co-Mo-W sulfide catalysts supported on SBA-15 and SBA-16 mechanically mixed. Catal Today 271: 114-126.

[38] Awoke Y, Chebude Y, Díaz I, (2020) Controlling Particle Morphology and Pore Size in the Synthesis of Ordered Mesoporous Materials Molecules 25 : 4909-4921.

[39] Know DW, Nam KB, Hong SC, (2015) Influence of tungsten on the activity of a Mn/Ce/W/Ti catalyst for the selective catalytic reduction of $\mathrm{NO}$ with $\mathrm{NH}_{3}$ at low temperatures. Appl Catal A Gen 497:160-166.

[40] Tang Q, Hu S, Chen Y, Guo Z, Hu Y, Chen Y, Yang Y, (2010) Highly dispersed manganese oxide catalysts grafted on SBA-15 Synthesis, characterization and catalytic application in trans-stilbene epoxidation. Micropor Mesopor Mater 132: 501-509.

[41] Mahdavi V, Mardani M, (2015) Preparation of manganese oxide immobilized on SBA-15 by atomic layer deposition as an efficient and reusable catalyst for selective oxidation of benzyl alcohol in the liquid phase. Mater Chem Phys 155:136-146.

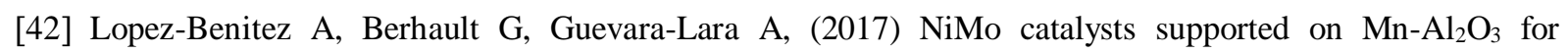
dibenzothiophene hydrodesulfurization application. Appl Catal B Environ 213 : 28-41.

[43] Imran G, Maheswari R, (2015) Mn-incorporated SBA-1 cubic mesoporous silicates: Synthesis and characterization, Mater. Chem. Phys. 161 237-242.

[44] Zhong W, Robert Kirk S, Yin D, Li Y, Zou R, Mao L, Zou G, (2015) Solvent free selective oxidation of toluene by oxygen over MnOx/SBA-15 catalysts: Relationship between catalytic behavior and surface structure. Chem Eng J 280: 737-747.

[45] Anbazhagan N, Imran G, Qurashi A, Pandurangan A, Manimaran S, (2017) Confinement of $\mathrm{Mn}^{3+}$ redox sites in Mn-KIT-6 and its catalytic activity for styrene epoxidation. Micropor Mesopor Mater 247:190-197.

[46] Liu G, Sun L, Liu J, Wang F, Guild C, (2017) Aerobic oxidation of primary amines into corresponding nitriles over $\mathrm{Mn}_{\mathrm{x}} \mathrm{Ce}_{1-\mathrm{x}} \mathrm{O}_{\mathrm{s}}$ catalysts prepared by co-impregnation method. J Mol Catal 440:148-157.

[47] Larrubia MA, Ramis G, Busca G, (2000) An FT-IR study of the adsorption of urea and ammonia over $\mathrm{V}_{2} \mathrm{O}_{5}$ $\mathrm{MoO}_{3}-\mathrm{TiO}_{2}$ SCR catalysts. Appl Catal B Environ 72:145-151.

[48] Jia B, Guo J, Luo H, Shu S, Fang N, Li J, (2018) Study of NO removal and resistance to $\mathrm{SO} 2$ and $\mathrm{H}_{2} \mathrm{O}$ of $\mathrm{MnOx} / \mathrm{TiO}_{2}, \mathrm{MnOx} / \mathrm{ZrO}_{2}$ and $\mathrm{MnOx} / \mathrm{ZrO}_{2}-\mathrm{TiO}_{2}$. Appl Catal A Gen 553: 82-90.

[49] Ismail R, Arfaoui J, Ksibi Z, Ghorbel A, Delahay G, (2020) Ag/ZrO 2 and Ag/Fe-ZrO ${ }_{2}$ catalysts for the low temperature total oxidation of toluene in the presence of water vapor. Transit Met Chem 45: 501-509. 
[50] Ismail R, Arfaoui J, Ksibi Z, Ghorbel A, Delahay G, (2020) Effect of the iron amount on the physicochemical properties of $\mathrm{Fe}-\mathrm{ZrO}_{2}$ aerogel catalysts for the total oxidation of toluene in the presence of water vapor. $\mathbf{J}$ Porous Mat 27: 1847-1852.

[51] You X, Sheng Z, Yu D, Yang L, Xiao X, Wang S, (2017) Influence of Mn/Ce ratio on the physicochemical properties and catalytic performance of graphene supported $\mathrm{MnOx}-\mathrm{CeO}_{2}$ oxides for $\mathrm{NH}_{3}-\mathrm{SCR}$ at low temperature Appl. Surf. Sci. 423: 845-854.

[52] Liu J, Guo RT, Li MY, Sun P, Liu SM, Pan WG, Liu SW, (2018) Sun X, Enhancement of the $\mathrm{SO}_{2}$ resistance of $\mathrm{Mn} / \mathrm{TiO}_{2}$ SCR catalyst by Eu modification A mechanism study. Fuel 223: 385-393.

[53] Tang XF, Li JH, Sun L, Hao JM, (2016) Manganese oxide-based catalysts for low-temperature selective catalytic reduction of $\mathrm{NO}_{x}$ with $\mathrm{NH}_{3}$ A review. Appl Catal A Gen 522: 54-69. 